DE

M E D I C I N A

T R O P I C A L

$\mathrm{DE}$

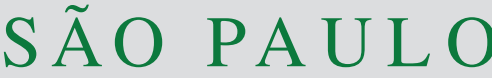

JOURNAL OF THE SÃO PAULO INSTITUTE OF TROPICAL MEDICINE

${ }^{1}$ Instituto Adolfo Lutz, Núcleo de Morfologia e Microscopia, São Paulo, São Paulo, Brazil

${ }^{2}$ Instituto Adolfo Lutz, Centro de Parasitologia e Micologia, São Paulo, São Paulo, Brazil

Correspondence to: Vera Lucia PereiraChioccola

Instituto Adolfo Lutz, Centro de

Parasitologia e Micologia, Av. Dr. Arnaldo, $351,8^{\circ}$ andar, CEP 01246-902, São Paulo, SP, Brazil

Tel: +55 1130682991

E-mail: pchioccola@gmail.com

Received: 1 June 2020

Accepted: 1 October 2020

\section{Determination of the viability of Toxoplasma gondii oocysts by PCR real-time after treatment with propidium monoazide}

\author{
Maria Aparecida Moraes Marciano1, Rafaela Aparecida Silva1, Maria Luisa \\ Barbosa $^{1}$, Antônio Roberto Souza Ferreira' ${ }^{1}$, Vera Lucia Pereira-Chioccola ${ }^{(i)} 2$
}

\section{ABSTRACT}

This study aimed to investigate a methodology for discriminating viable and non-viable T. gondii oocysts in water. Analyses included two steps: (i) microscopic investigation with vital dyes; (ii) molecular investigation, using a real time PCR (qPCR), after parasite treatment (or not) with propidium monoazide (PMA). The method was called qPCR-PMA. Oocyst aliquots were incubated $(15 \mathrm{~min})$ at $25^{\circ} \mathrm{C}$ or $100^{\circ} \mathrm{C}$ and analyzed by microscopy, after trypan blue and neutral red staining. Microscopic investigation determined viable and non-viable oocysts. For the molecular investigation, both aliquots of oocysts were treated with PMA. Non-viable oocysts, after PMA treatment, exhibited an inhibition of DNA amplification by qPCR. Although analyses were carried out with oocysts treated experimentally, these results suggest that qPCR-PMA can be a useful strategy to distinguish viable and non-viable T. gondii oocysts in water safety testing, showing if water is safe to drink.

KEYWORDS: Viability. Toxoplasma gondii. Oocysts. Vital dyes. Propidium monoazide. Real time PCR.

\section{INTRODUCTION}

Waterborne parasites affect many populations in the world, especially in outbreaks. In the last years, various factors were related to dissemination of these pathogens such as, increased contamination of drinking water and food; increase of susceptible people; changes in the drinking water treatment technology; and globalization ${ }^{1}$. The high morbidity and mortality of populations caused by contaminated drinking water have been relevant in the last years. Thus, this condition must be controlled by improving the quality and the safety of drinking water $^{2,3}$.

Among the main waterborne parasites, Toxoplasma gondii affects about a third of the world population ${ }^{4}$. T. gondii is an obligate intracellular parasite that infects a wide range of warm-blooded vertebrates (mammals and birds) as intermediate hosts, in which the asexual cycle takes place with formation of tissue cysts within cells. The felines are the definitive hosts of this protozoan, whose sexual cycle culminates with the production of oocysts eliminated in the feces thereafter contaminating the environment ${ }^{5-7}$.

Although the majority of toxoplasmosis cases is asymptomatic, around 10-20\% of infected individuals can develop the ocular form of toxoplasmosis associated with congenital infections or acquired after birth. In immunocompromised individuals, the infection may cause serious destructive inflammatory lesions in the central nervous system, known as cerebral toxoplasmosis ${ }^{7-10}$. Other important clinical and 
social implications have been reported in association with schizophrenia and bipolar disorder ${ }^{11-15}$.

The main routes of $T$. gondii transmission includes the transplacental, from the mother to the fetus during the primary infection; the ingestion of cysts present in infected animal tissues; and the ingestion of water or contaminated food by oocysts ${ }^{16,17}$.

Unsporulated oocysts are subspherical to spherical with walls composed of two colorless layers. Polar granules are absent, and the sporont almost fills the oocyst. Sporulation occurs outside the definitive host, within 1 to 5 days of excretion depending upon the environment aeration and temperature ${ }^{5,7,18}$.

Sporulated oocysts are subspherical to ellipsoidal and contain two ellipsoidal sporocysts. In this phase, oocysts are viable for at least one year, resisting to temperatures between $20^{\circ} \mathrm{C}$ and $37.5^{\circ} \mathrm{C}$. They survive and remain infective for 12 to 18 months in ideal environmental conditions depending on the humidity, temperature and shading place conditions. Sporulated oocysts maintained in laboratory can remain infective at $35^{\circ} \mathrm{C}$ for 32 days, at $40{ }^{\circ} \mathrm{C}$ for 9 days, and at $45^{\circ} \mathrm{C}$ for 1 day. They survive at $4{ }^{\circ} \mathrm{C}$ for 54 months, and frozen at $-10{ }^{\circ} \mathrm{C}$ for 106 days ${ }^{18,19}$.

Oocysts can survive in water for long periods and are highly resistant to several chemical inactivation processes. This property favors the occurrence of many outbreaks caused by T. gondii in different world regions. Most of them are associated with water contamination by oocysts ${ }^{20-23}$.

Although the polymerase chain reaction (PCR) has contributed significantly to the diagnosis of toxoplasmosis in clinical samples, the viability of oocysts in water samples collected in places where outbreaks have occurred are not well established. The water safety can be reduced by a low detection of viable pathogens. Therefore, it is important to determine the parasite viability in water. In general, the usual approach is the parasite analysis in light microscopy after the sample staining by vital dyes.

Recently, a useful strategy to identify live pathogens in food or water has been described, the use of propidium monoazide (PMA) that is a photoreactive DNA-binding dye. Dead pathogens lose the ability to keep their membranes intact. Thus, DNA is free in cytosol, ready to react with PMA that can penetrate in membrane-compromised cells. Live pathogens are not exposed to PMA, as they have intact cell membranes. The qPCR-PMA includes DNA extraction and real time PCR (qPCR) amplification of PMA-treated samples to efficiently detect non-viable pathogens ${ }^{24-26}$.

This study was aimed to investigate a methodology for discriminating viable and non-viable $T$. gondii oocysts in water. In order to identify whether only a molecular method could be efficient in this situation, we analyzed two methods. The first one was the microscopic investigation after parasites treatment with vital dyes. The second one was the molecular investigation, using qPCR-PMA, which includes parasite treatment with PMA and posterior amplification by qPCR.

\section{MATERIALS AND METHODS}

\section{T. gondii oocysts}

Stool samples containing non-sporulated oocysts of cats experimentally infected with $T$. gondii (Br1 strain) were collected in the Centro de Ciencias Agrarias, Departamento de Medicina Veterinaria Preventiva, Universidade Estadual de Londrina, Parana State, Brazil. After the stool samples collection, they were kindly provided for this study and were maintained at $4{ }^{\circ} \mathrm{C}$, including the period of transportation to our laboratory.

\section{Purification and concentration of T. gondii oocysts}

T. gondii non-sporulated oocysts were isolated, purified and concentrated from stools by flotation and centrifugation using sucrose. During all laboratory steps, oocysts were maintained at $4{ }^{\circ} \mathrm{C}$ to prevent sporulation. Cat stools ( $3 \mathrm{~g}$ ) were mixed with saturated sucrose solution $(10 \mathrm{~mL})$, vigorously stirred for $30 \mathrm{~s}$, and centrifuged at $400 \mathrm{x}$ g for $20 \mathrm{~min}$ at $4{ }^{\circ} \mathrm{C}$. The upper layer of the supernatant $(4 \mathrm{~mL})$ was transferred to a new tube and washed $(4700 \mathrm{x} \mathrm{g}$ for $5 \mathrm{~min})$ in distilled water $(10 \mathrm{~mL})$.

Purified oocysts (in $10 \mathrm{~mL}$ ) were counted in a Neubauer chamber. The recuperation of oocysts was $2.3 \times 10^{5} / \mathrm{mL}$. Firstly, oocysts were used to establish a standard qPCR curve. Next, oocysts were divided into 2 aliquots of $500 \mu \mathrm{L}$ to be used in the experiments. One aliquot was incubated at $25^{\circ} \mathrm{C}$ for $15 \mathrm{~min}$, and the second aliquot was incubated at $100{ }^{\circ} \mathrm{C}$ for $15 \mathrm{~min}$. Then, both aliquots were stored at $4{ }^{\circ} \mathrm{C}$ until and used in the staining and photo-activation experiments.

\section{Oocyst treatment with vital dyes}

Viability of $T$. gondii oocysts was, firstly, tested using trypan blue $0.4 \%$, which dyes only cells with damaged external membrane. Both oocyst aliquots (incubated at $25^{\circ} \mathrm{C}$ and at $100^{\circ} \mathrm{C}$ ) were stained with trypan Blue $0.4 \% \mathrm{v} / \mathrm{v}$ at room temperature for $15 \mathrm{~min}$. In addition, both aliquots were stained with $2.0 \%$ neutral red that dyes only viable cells. Oocysts were incubated with $2.0 \% \mathrm{v} / \mathrm{v}$ neutral red, at room temperature in a dark room for $3 \mathrm{~h}$. A volume of $20 \mu \mathrm{L}$ of each aliquot was added to glass slides and coverslips and 
analyzed in a 400 -fold magnification using a Zeiss ${ }^{\circledR}$ Primo Star optical microscope (Jena, Germany).

\section{Oocyst treatment with PMA}

For PMA treatment, experiments were performed as described before ${ }^{24-26}$. Three aliquots at concentrations of $2.3 \times 10^{5} / \mathrm{mL}$ were tested. The first and second were composed of oocysts incubated at $25{ }^{\circ} \mathrm{C}$ and at $100{ }^{\circ} \mathrm{C}$, respectively. The third aliquot was composed of a mix containing viable and non-viable oocysts (v/v). Then, the mixture was divided into 2 aliquots and only one was treated with PMA. Both aliquots were serially diluted (1:1, 1:2, 1:4, 1:8 and 1:16). Each dilution was amplified by qPCR-PMA, after DNA purification. The aim of the third aliquot testing was to determine the DNA concentration capable of distinguishing viable and non-viable oocysts after PMA treatment. In order to determine the DNA concentration of oocysts, a standard curve was constructed for the REP-529 primer set (see Real time PCR item).

To each aliquot $(180 \mu \mathrm{L}), 20 \mu \mathrm{L}$ of PMA $2 \mathrm{mM}$ were added (Biotium Inc., Hayward, WI, USA) to obtain a final concentration of $200 \mu \mathrm{M}$. For the controls, one tube of each aliquot received water instead of PMA. The solutions were maintained in a dark room for $30 \mathrm{~min}$ at room temperature. For PMA photoactivation, the tubes were packed in a plastic bag containing fragmented ice (ice bed) at a distance of approximately $15 \mathrm{~cm}$ from each other, and they were exposed to white light for $30 \mathrm{~min}$. A $500 \mathrm{~W}$ halogen lamp was used for the light emission. Next, these aliquots were used for DNA purification and qPCR.

\section{DNA purification}

Oocyst aliquots ( $200 \mu \mathrm{L}$ ) were digested for 12 to $18 \mathrm{~h}$ at $56{ }^{\circ} \mathrm{C}$ with proteinase $\mathrm{K}(20 \mu \mathrm{g})$ in $40 \mu \mathrm{L}$ of $\mathrm{AL}$ buffer (QIAGEN) ) under agitation. DNA was extracted using the QIAamp DNA Mini Kit (QIAGEN, Hilden, Germany). The protocol was performed according to the manufacturer's instructions. DNA concentration and purity were determined by the ratio of the reading at $260 \mathrm{~nm}$ wavelength divided by the reading at $280 \mathrm{~nm}$ in the NanoDrop ND 1000 (Thermo Fisher Scientific, Waltham, USA). DNA samples were diluted in ultra-pure water until a concentration of $100 \mathrm{ng} / \mu \mathrm{L}$ for use in $\mathrm{qPCR}^{27}$.

\section{Real time PCR (qPCR)}

Reactions were performed as previously described ${ }^{27,28}$. The primer set used for qPCR amplified a fragment of 112-bp of a highly repetitive sequence named REP-529, which has 200-300 copies per T. gondii genome ${ }^{29}$. The qPCR primer set is composed of a forward primer (5' -AGAGACACCGGAATGCGATC T- 3'), and a reverse one (5'-TTCGTCCAAGCCTCCGACT-3') primers and hybridization probe (5'-TCGTGGTGATGGCGGAGAGAATTGA-3') labeled with FAM and BHQ1. The reactions were performed in a final volume of $20 \mu \mathrm{L}$. DNA samples ( $3 \mu \mathrm{L}$ of DNA containing up to $100 \mathrm{ng} / \mu \mathrm{L})$, a control DNA $(5 \mathrm{ng} / \mu \mathrm{L})$ and DNA dilutions to construct the standard curve ( $3 \mu \mathrm{L}$ for each point) were added to the reaction mixture containing $10 \mu \mathrm{L}$ of 2 X TaqMan Universal PCR Master Mix; $1.25 \mu \mathrm{L}$ of the other reagents mix (18 $\mu \mathrm{M}$ of forward and reverse primers and $5 \mu \mathrm{M}$ of the hydrolysis probe). Each amplification run contained two negative controls (ultra-pure water and a human toxoplasmosis-negative DNA sample). Amplifications were performed in an Applied Biosystems 7500 Real-time PCR System using the following thermal profile: $2 \mathrm{~min}, 50^{\circ} \mathrm{C}$, and $95^{\circ} \mathrm{C}$ for $10 \mathrm{~min}$. Next, 40 cycles were performed at $95^{\circ} \mathrm{C}$ for $15 \mathrm{~s}$ and $60{ }^{\circ} \mathrm{C}$ for $1 \mathrm{~min}$.

The standard curve for REP-529 primer set was constructed testing six DNA concentrations obtained from $1 \times 10^{6}$ oocysts containing $50 \mathrm{ng} / \mu \mathrm{L}$. Serial dilutions ranged up to 10 oocysts. Cycle quantification values $(\mathrm{Cq})$ were plotted as the mean of triplicates. Parasite concentrations were determined after the calculation of the linear regression equation $(\mathrm{y}=\mathrm{ax}+\mathrm{b})$, where $\mathrm{y}=\mathrm{Cq} ; \mathrm{a}=$ slope curve; $\mathrm{x}=$ parasite number in $\log _{10} ; \mathrm{b}=$ the point in which the curve intersects the $y$-axis (y intercept $)^{30,31}$.

Comparison of the number of oocysts after qPCR amplification, between PMA-treated or non-treated samples were statistically evaluated by the GraphPad Prism Software (version 6.0, Prism Software Inc., San Diego, CA, USA). The coefficient of similarity between both groups was calculated by the one-tailed unpaired Student's $t$-Test with a $95 \%$ confidence interval. Differences were considered statistically significant when the $p$ value was 0.05 .

\section{RESULTS}

Microscopic exams demonstrated that oocysts were totally preserved in the aliquot incubated at $25^{\circ} \mathrm{C}$. However, oocysts were ruptured in the second aliquot incubated at $100{ }^{\circ} \mathrm{C}$. To confirm these data, aliquots were dyed with $0.4 \%$ trypan blue. Preserved oocysts had whole wall surfaces without dye entry inside them (Figure 1A). On the other hand, Figure $1 \mathrm{~B}$ shows oocysts after incubation at $100{ }^{\circ} \mathrm{C}$ presenting with deformities and dye penetration inside them after treatment with $0.4 \%$ trypan blue. At the same time, Figure $1 \mathrm{C}$ shows a viable oocyst impregnated with the $2.0 \%$ neutral red after an incubation period, confirming 
the integrity of the oocysts wall. The oocysts incubated at $100{ }^{\circ} \mathrm{C}$ were not stained with the neutral red, showing the unviability caused by the boiling treatment (Figure 1D).
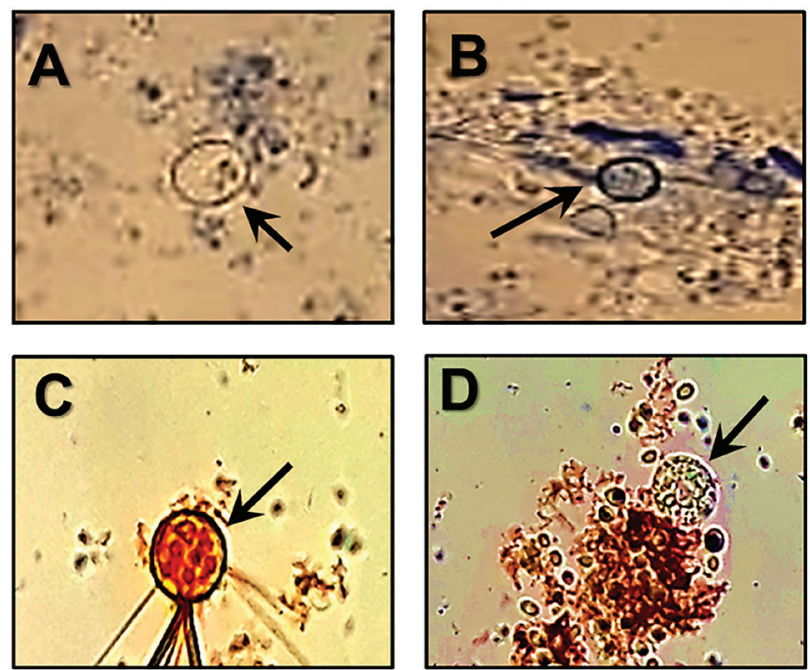

Figure 1 - Microscopic investigation: determination of the viability of oocysts. Images captured by light microscopy of purified oocysts with intact membranes after incubation at $25^{\circ} \mathrm{C}$ for 15 min, stained with trypan blue (A); and with neutral red (C). Images captured by light microscopy of purified oocysts after incubation at $100{ }^{\circ} \mathrm{C}$ for 15 min with damaged oocyst walls, stained with trypan blue (B); and with neutral red (D). Magnification: X 400. The arrows indicate oocysts.

In addition, the viability of oocysts was tested by molecular methods. Firstly, a standard curve of REP-529 primers was constructed testing DNA purified from oocysts. As shown in Figure 2A, the resulting standard curve displayed a $R_{2}$ value $=0.9953^{31}$, meaning that there is a high linearity among the variables.

Figure 2B show the results of PMA-qPCR of oocysts treated or non-treated with PMA. Oocysts incubated at $100{ }^{\circ} \mathrm{C}$ (non-treated) had walls rupture and their mean oocyst concentration was $1.75 \times 10^{5}$. In contrast, oocysts incubated at $100^{\circ} \mathrm{C}$ and treated with PMA had a much lower qPCR-PMA amplification with a mean of oocysts of 33.5. According to the unpaired Student's $t$-Test, the reduction of qPCR-PMA amplification was statistically significant $(p=0.0198)$.

DNA of oocysts incubated at $25{ }^{\circ} \mathrm{C}$ (treated or nontreated with PMA) had a mean of oocysts in qPCR-PMA of $1.03 \times 10^{6}$ (non-treated) and $1.72 \times 10^{3}$ (treated). Even though, there was no significant statistical difference between both samples $(p=0.4223)$. The next experiment was performed to identify whether qPCR-PMA differences observed in this experiment could be confirmed using oocysts serial dilutions. Figure $2 \mathrm{C}$ shows qPCR-PMA results of serial-diluted oocysts and PMA non-treated samples. However, these serial diluted and PMA-treated

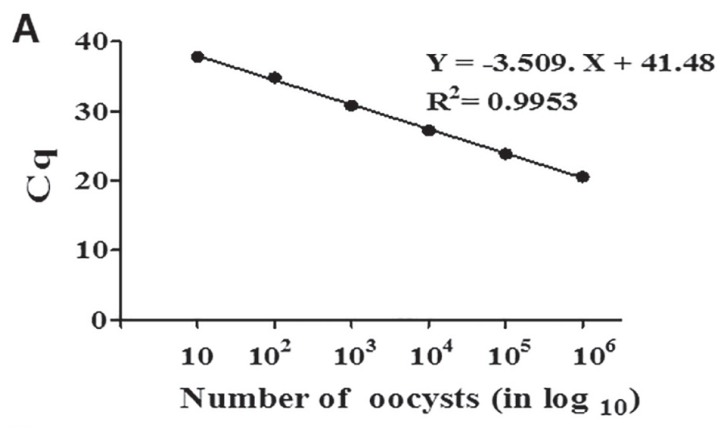

B

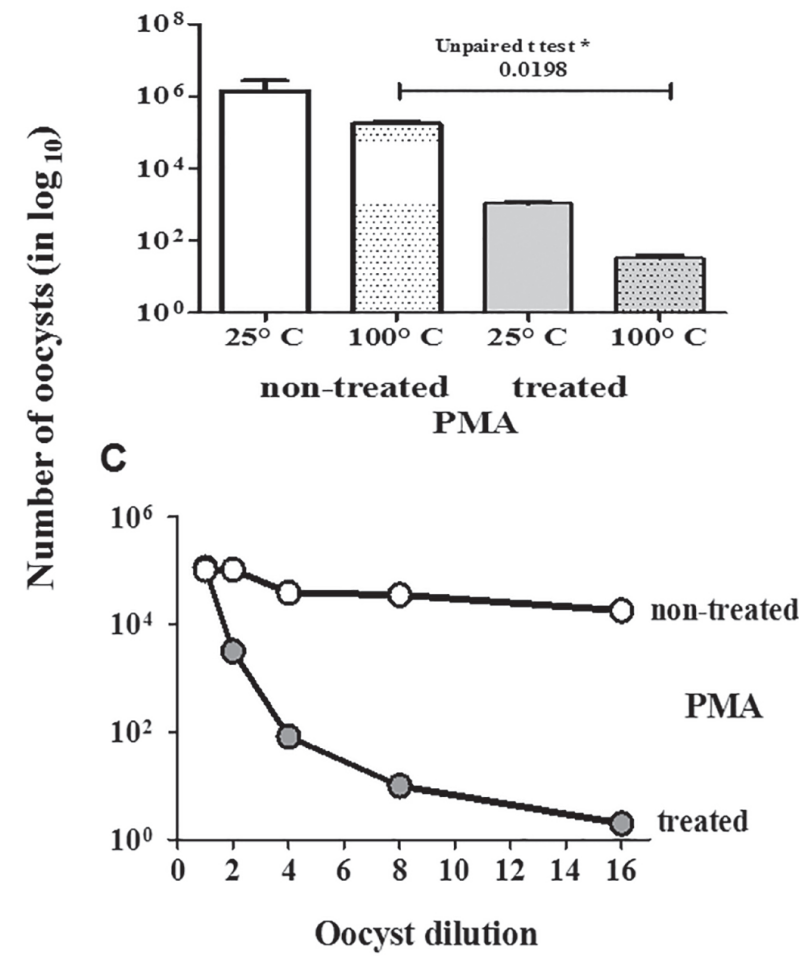

Figure 2 - Molecular investigation: determination of the viability of oocysts. (A) qPCR-standard curve of T. gondii oocysts using the REP-529 primer set with a hydrolysis probe FAM dyelabeled. Results are shown as means of the cycle quantification value $(\mathrm{Cq})$ obtained from triplicates of each DNA concentration. Analyses were carried out in 10-fold serial dilutions of DNA extracted from oocysts, in an initial concentration of $50 \mathrm{ng} / \mu \mathrm{L}$ ( 1 x $10^{6}$ oocysts). R2=0.9923; (B) qPCR-PMA: oocysts incubated at $25^{\circ} \mathrm{C}$ or at $100{ }^{\circ} \mathrm{C}$, non-treated (white bars) and PMA-treated (gray bars); (C) qPCR-PMA: two mixtures containing viable and non-viable oocysts, PMA-treated (gray circles) or non-treated (white circles) were serialyl diluted and qPCR was performed. Results in (B) and (C) represent the oocyst number derived from $\mathrm{Cq}$ values and calculated from the standard curve.

oocysts showed a significant qPCR-PMA inhibition when compared to those without PMA treatment.

\section{DISCUSSION}

T. gondii oocysts spread in the environment, including 
water reservoirs, are an important source of infection for humans and animals. Consequently, this situation affects a great part of the world population ${ }^{20,21}$.

The life time of oocysts has been investigated regarding their infectivity by means of experimental contamination of animals with soil samples. Nevertheless, viability of oocysts in the environment, such as water reservoirs has been poorly documented and this type of study can contribute to an effective monitoring of the quality of drinking water ${ }^{6,7,32}$.

The investigation of parasites viability should be included in T. gondii diagnosis in water samples, as only viable parasites are infective. This observation is important as some previously treated drinking water samples, may contain viable or non-viable oocysts. Thus, the knowledge on the viability of T. gondii oocysts is critical in public health to prevent the environmental transmission of parasites.

Incubation at $100^{\circ} \mathrm{C}$ in short exposure times was unable to break through all the wall of the oocysts. After boiling $\left(100{ }^{\circ} \mathrm{C}\right)$ for $15 \mathrm{~min}$, some oocysts kept the walls intact. Both, trypan blue and neutral red dyes for microscopy exams are easy to do methods to observe oocysts with or without compromised walls. However, the observations must be performed by an experienced technician, as it is difficult to visualize oocysts on stained slides containing low parasite concentrations.

The difficulties encountered to achieve reliable and sensitive microscopy evaluations led different laboratories to study the efficiency of PCR (conventional or real-time), which has been shown as an important diagnostic tool. The molecular detection of $T$. gondii has been widely used to analyze clinical, veterinary and environment samples ${ }^{27,33}$. However, results are unable to determine whether the detected DNA came from viable or non-viable parasites ${ }^{34}$.

This study chose to use the PMA, a photo-reactive DNA compound for the molecular investigation of the viability of oocysts. The qPCR-PMA is promising as it presents with good sensitivity and rapid results to discriminate viable and non-viable $T$. gondii oocysts ${ }^{26,35}$. The only flaw of this technique is the possibility of the amplification inhibition when PMA is present due to a lack of accessibility to DNA caused by the presence of DNA/PMA complexes.

PMA penetrates into dead cells with damaged walls, then it is interleaved in nucleic acids after photoactivation. As the majority of natural DNA does not exist in cells, the number of molecules is reduced and Cq values increased ${ }^{25}$. In this way, only viable cells have intact DNA.

T. gondii oocysts have a bilayered wall that surrounds the sporozoites. As a result, they are impermeable to watersoluble molecules ${ }^{34,36}$. Previous studies demonstrated that the length of amplified DNA plays a crucial role in the suppression of qPCR-PMA ${ }^{37}$. Using qPCR, signals were suppressed in PMA-treated DNA from Giardia duodenalis cysts using a primer set that amplifies a 605-bp fragment, but suppression did not occur when a 77-bp product was amplified $^{38}$. Similar results were shown in qPCR-PMA, whose primer sets amplified a 180-bp product, and the inhibition was observed in the case of a 834-bp product from the 18S gene of Cryptosporidium parvum oocysts ${ }^{39}$. In this study, the suppression effect of qPCR-PMA signals was not noticed, as described by Contreras et al. ${ }^{37}$ as reactions were performed using a primer set that amplifies a small fragment (112-bp) of $T$. gondii REP-529 sequence. In addition, REP-529 is a highly repetitive sequence with 200-300 copies in a single T. gondii genome. This methodology is highly used in clinical diagnosis ${ }^{27,28}$ and environment investigations ${ }^{40}$, due to its high sensitivity and specificity. Similarly, in the present study, qPCR-PMA was able to discriminate viable and non-viable oocysts with good efficiency. However, the discrimination of viable and non-viable oocysts was only possible after oocysts were sequentially diluted, as shown in Figure 2C.

\section{CONCLUSIONS}

The qPCR-PMA methodology was efficient to determine the viability of $T$. gondii oocysts in water samples, although, in this study the analyses were carried out with experimentally ruptured oocysts. These data suggest that qPCR-PMA can be a useful strategy for distinguishing viable and non-viable $T$. gondii oocysts in water safety tests, showing if water is safe to drink.

\section{AUTHORS' CONTRIBUTIONS}

VLPC and MAMA designed the study, coordinated the experiments and wrote the manuscript; MAMA and RAS conducted the experiments of purification and treatment of oocysts; MAMA, RAS and ARSF performed the experiments using microscopy; MAMA, MLB and VLPC performed and analyzed the molecular experiments. All authors contributed substantially to the interpretation of the data and to the manuscript. In addition, all authors revised the manuscript, approved the final version submitted, published, and agreed to be accountable for all aspects of the study, ensuring that questions related to the accuracy or integrity of any part of the work were appropriately investigated and resolved.

\section{CONFLICT OF INTERESTS}

The authors declare that the research was conducted in the absence of any commercial or financial relationships that could be a potential conflict of interest. 


\section{FUNDING}

VLPC was supported by a scholarship from CNPq (Conselho Nacional de Desenvolvimento Científico e Tecnológico), grant $\mathrm{N}^{\mathrm{o}} 302327 / 2018-5$.

\section{REFERENCES}

1. Ramírez-Castillo FY, Loera-Muro A, Jacques M, Garneau P, Avelar-González FJ, Harel J, et al. Waterborne pathogens: detection methods and challenges. Pathogens. 2015;4:307-34

2. Pandey PK, Kass PH, Soupir ML, Biswas S, Singh VP. Contamination of water resources by pathogenic bacteria AMB Express. 2014;4:51

3. World Health Organization. Progress on drinking water and sanitation: 2014 update. Geneva: WHO; 2014. [cited 2020 Oct 5]. Available from: https://www.who.int/water_sanitation_ health/publications/2014/jmp-report/en/

4. Montoya JG, Liesenfeld O. Toxoplasmosis. Lancet. 2004;363:1965-76.

5. Fishback JL, Frenkel JK. Toxoplasmosis. Semin Vet Med Surg Small Anim. 1991;6:219-26.

6. Dubey JP. Advances in the life cycle of Toxoplasma gondii. Int J Parasitol. 1998;28:1019-24.

7. Dubey JP. History of the discovery of the life cycle of Toxoplasma gondii. Int J Parasitol. 2009;39:877-82.

8. Pereira-Chioccola VL, Vidal JE, Su C. Toxoplasma gondii infection and cerebral toxoplasmosis in HIV-infected patients. Future Microbiol. 2009;4:1363-79.

9. Saadatnia G, Golkar M. A review on human toxoplasmosis. Scand J Infect Dis. 2012;44:805-14.

10. Butler NJ, Furtado JM, Winthrop KL, Smith JR. Ocular toxoplasmosis II: clinical features, pathology and management. Clin Exp Ophthalmol. 2013;41:95-108.

11. Kapperud G, Jenum PA, Stray-Pedersen B, Melby KK, Eskild A, Eng J. Risk factors for Toxoplasma gondii infection in pregnancy: results of a prospective case-control study in Norway. Am J Epidemiol. 1996;144:405-12.

12. Fabiani S, Pinto B, Bonuccelli U, Bruschi F. Neurobiological studies on the relationship between toxoplasmosis and neuropsychiatric diseases. J Neurol Sci. 2015;351:3-8.

13. Ngoungou EB, Bhalla D, Nzoghe A, Dardé ML, Preux PM. Toxoplasmosis and epilepsy: systematic review and meta analysis. PLoS Negl Trop Dis. 2015;9:e0003525.

14. Murata FH, Ferreira MN, Camargo NS, Santos GS, Spegiorin LC, Silveira-Carvalho AP, et al. Frequency of anti- Toxoplasma gondii $\operatorname{Ig} \mathrm{A}, \operatorname{IgM}$, and $\mathrm{IgG}$ antibodies in high-risk pregnancies, in Brazil. Rev Soc Bras Med Trop. 2016;49:512-4.

15. Fuglewicz AJ, Piotrowski P, Stodolak A. Relationship between toxoplasmosis and schizophrenia: a review. Adv Clin Exp Med. 2017;26:1031-6.
16. Tenter AM, Heckeroth AR, Weiss LM. Toxoplasma gondii: from animals to humans. Int J Parasitol. 2000;30:1217-58.

17. Dubey JP, Lago EG, Gennari SM, Su C, Jones JL Toxoplasmosis in humans and animals in Brazil: high prevalence, high burden of disease, and epidemiology. Parasitology. 2012;139: 1375-424.

18. Dubey JP, Lindsay DS, Speer CA. Structures of Toxoplasma gondii tachyzoites, bradyzoites, and sporozoites and biology and development of tissue cysts. Clin Microbiol Rev. 1998;11:267-99.

19. Petersen E, Vesco G, Villari S, Buffolano W. What do we know about risk factors for infection in humans with Toxoplasma gondii and how can we prevent infections? Zoonoses Public Health. 2010;57:8-17.

20. de Moura L, Bahia-Oliveira LM, Wada MY, Jones JL, Tuboi SH, Carmo EH, et al. Waterborne toxoplasmosis, Brazil, from field to gene. Emer Infect Dis. 2006;12:326-9.

21. Baldursson S, Karanis P. Waterborne transmission of protozoan parasites: review of worldwide outbreaks: an update 2004 2010. Water Res. 2011;45:6603-14.

22. Meireles LR, Ekman CC, Andrade Jr HF, Luna EJ. Human toxoplasmosis outbreaks and the agent infecting form findings from a systematic review. Rev Inst Med Trop Sao Paulo. 2015;57:369-76.

23. Galvani AT, Christ AP, Padula JA, Barbosa MR, Araújo RS, Sato MI, et al. Real-time PCR detection of Toxoplasma gondii in surface water samples in São Paulo, Brazil. Parasitol Res. 2019;118:631-40.

24. Lee ES, Lee MH, Kim BS. Evaluation of propidium monoazidequantitative PCR to detect viable Mycobacterium fortuitum after chlorine, ozone, and ultraviolet disinfection. Int J Food Microbiol. 2015;210:143-8.

25. Li Y, Huang TY, Ye C, Chen L, Liang Y, Wang K, Liu J. Formation and control of the viable but non-culturable state of foodborne pathogen Escherichia coli O157:H7. Front Microbiol. 2020;11:1202

26. Rousseau A, Villena I, Dumètre A, Escotte-Binet S, Favennec L, Dubey JP, et al. Evaluation of propidium monoazide-based qPCR to detect viable oocysts of Toxoplasma gondii. Parasitol Res. 2019;118:999-1010.

27. Camilo LM, Pereira-Chioccola VL, Gava R, Meira-Strejevitch CS, Vidal JE, Brandão de Mattos CC, et al. Molecular diagnosis of symptomatic toxoplasmosis: a 9-year retrospective and prospective study in a referral laboratory in São Paulo. Braz J Infect Dis. 2017;21:638-47.

28. Robert-Gangneux F, Dupretz P, Yvenou C, Quinio D, Poulain P, Guiguen $\mathrm{C}$, et al. Clinical relevance of placenta examination for the diagnosis of congenital toxoplasmosis. Pediatr Infect Dis J. 2010;29:33-8.

29. Homan WL, Vercammen M, De Braekeleer J, Verschueren H. Identification of a 200- to 300-fold repetitive 529 bp DNA 
fragment in Toxoplasma gondii, and its use for diagnostic and quantitative PCR. Inter J Parasitol. 2000;30:69-75.

30. Bustin SA, Benes V, Garson JA, Hellemans J, Huggett J, Kubista $\mathrm{M}$, et al. The MIQE guidelines: minimum information for publication of quantitative real-time PCR experiments. Clin Chem. 2009;55:611-22.

31. Broeders S, Huber I, Grohmann L, Berben G, Taverniers I, Mazzara M, et al. Guidelines for validation of qualitative realtime PCR methods. Trends Food Sci Technol. 2014;37:115-26.

32. Dumètre A, Dardé ML. Purification of Toxoplasma gondii oocysts by cesium chloride gradient. J Microbiol Methods 2004;56:427-30.

33. Lass A, Pietkiewicz H, Szostakowska B, Myjak P. The first detection of Toxoplasma gondii DNA in environmental fruits and vegetables samples Eur J Clin Microbiol Infect Dis. 2012;31:1101-8

34. Rousseau A, La Carbona S, Dumètre A, Robertson LJ, Gargala G, Escotte-Binet S, et al. Assessing viability and infectivity of foodborne and waterborne stages (cysts/oocysts) of Giardia duodenalis, Cryptosporidium spp., and Toxoplasma gondii: a review of methods. Parasite. 2018;25:14.

35. Zeng D, Chen Z, Jiang Y, Xue F, Li B. Advances and challenges in viability detection of foodborne pathogens. Front Microbiol. 2016;7:1833.
36. Ferguson DJ, Hutchison WM, Siim JC. The ultrastructural development of the macrogamete and formation of the oocyst wall of Toxoplasma gondii. Acta Pathol Microbiol Scand B. 1975;83:491-505.

37. Contreras PJ, Urrutia H, Sossa K, Nocker A. Effect of PCR amplicon length on suppressing signals from membranecompromised cells by propidium monoazide treatment. J Microbiol Methods. 2011;87:89-95.

38. Alonso JL, Amorós I, Guy RA. Quantification of viable Giardia cysts and Cryptosporidium oocysts in wastewater using propidium monoazide quantitative real-time PCR. Parasitol Res. 2014;113:2671-8

39. Agulló-Barceló M, Moss JA, Green J, Gillespie S, Codony F, Lucena F, et al. Quantification of relative proportions of intact cells in microbiological samples using the example of Cryptosporidium parvum oocysts. Lett Appl Microbiol. 2014;58:70-8.

40. Yang W, Lindquist HD, Cama V, Schaefer FW, Villegas E, Fayer R, et al. Detection of Toxoplasma gondii oocysts in water sample concentrates by real-time PCR. Appl Environ Microbiol. 2009;75:3477-83. 